\title{
The Potential of “Ojhung” Tradition Art as Sports Tourism in Sumenep District
}

\author{
Febryansah Gilang Aris Pradana \\ Universitas Negeri Surabaya \\ Surabaya, Indonesia \\ febryansahpradana16060464058@mhs.unesa.ac.id
}

\author{
Asha \\ Universitas Negeri Surabaya \\ Surabaya, Indonesia \\ ashaasha16041184062@mhs.unesa.ac.id
}

\author{
Nurul Hidayat \\ Universitas Negeri Surabaya \\ Surabaya, Indonesia \\ nurul.1706046405@mhs.unesa.ac.id
}

\author{
Dwi Lorry Juniarisca \\ Universitas Negeri Surabaya \\ Surabaya, Indonesia \\ dwijuniarisca@unesa.ac.id
}

\author{
Ali Imron \\ Universitas Negeri Surabaya \\ Surabaya, Indonesia \\ aliimron@unesa.ac.id
}

\begin{abstract}
This research aims to describe the potential of the Ojhung tradition arts in Sumenep District. The benefits that could be taken were to preserve and develop the potential of Ojhung tradition arts as sport tourism. This research used a qualitative method. The data were obtained through data collection techniques in the form of interview observations, and literature studies. The data analysis technique used the Miles and Huberman model. The technique of checking the validity of the data is using triangulation. The results of this research can be concluded that the art of Ojhung tradition has the potential to become sport tourism in Sumenep District, because it has a tourism attraction, based on its requirements, namely, something that can be seen in the form of rituals asking for rain and Ojhung matches. The activities carried out in the form of participation in Ojhung matches. There is something that can be bought, in the form of culinary, Ojhung property and Sumenep District souvenirs.
\end{abstract}

\section{Keywords-Ojhung; tourism potential; sport tourism}

\section{INTRODUCTION}

The tourism sector is designated as an important sector to be developed in synergy as a leading sector. Through a sustainable tourism approach, it needs synergy, between natural and cultural conservation efforts and their inheritance to support the acceleration of national development [1], as well as in Sumenep District Madura.

Tourism is one of the leading sectors in Sumenep District. This is evidenced by the increasing number of tourist visits over the past two years. According to Sumenep District Government data, the number of tourists visiting this region in 2016 reached 800 thousand. In 2017, the number of visits rose
16 percent, reaching 1,049,000 tourists [2]. Sumenep District which established itself as Soul of Madura in 2018 has prepared 36 leading events. The series of events will be held in a full year in the form of festivals in the fields of culture, history, sports, religion, and health festivals. The series of events were carried out to achieve the target set by the Sumenep District government, which was to exceed the number of visits in the previous year. In order to develop the tourism sector and achieve the target of the district government, efforts need to be made in developing sustainable tourism [3]. Sustainable tourism development is the process of developing an area without reducing the use value of an existing resource. One of them is by developing alternative tourism. Alternative tourism is a tourism activity that does not damage the environment, avoids the negative impacts of largescale tourism that can threaten regional culture. One type of alternative tourism that has received much attention now is sports tourism [4].

Sport tourism is a relatively new and increasing industry in the tourism industry that focuses on planning targets in developing countries [5]. According to the Law of the Republic of Indonesia Number 3 of 2005 concerning the National Sports System [7] states that recreational sports are sports carried out by the community with the willingness and ability to grow and develop in accordance with the conditions and cultural values of the local community for health, fitness and pleasure. Based on this, sports and tourism have the same purpose. One area that has a big opportunity in developing sports tourism is Sumenep District.

Sumenep District Madura is known as an island that has a culture in the form of diverse arts and traditions. This culture 
has been preserved for generations. One of them is in Batu Putih Laok Village, Batu Putih Sub-District, it is Ojhung. Ojhung is a ritual or traditional ceremony that is carried out for requesting the fall of rain, but with time, Ojhung art has developed into traditional arts for public entertainment and games. As a means of entertainment, Ojhung arts are performed at an event such as at the event of carrying out nadzar (promises made by certain person to God) and village salvation or earth charity [8].

Ojhung is the art of fighting by beating each other and parrying the opponent's limbs by using a rattan brokered or guided by a referee. This art highlights the physical strength of the players. This form of art presentation is loaded with magical elements both from the players and the atmosphere when Ojhung art is held. In its implementation, Ojhung art was accompanied by an Okol orchestra consisting of a gambang and two tambur from wood or commonly called dhuk-dhuk [9]. The Okol Orchestra is a group of music players with a set of musical instruments in the interior of Sumenep District which are usually used as accompanists in various events, such as the dove and Ojhung matches

The art of the Ojhung tradition has the potential to be developed into a culture based sport tourism. In this case, culture-based sport tourism combines sports activities with the power of the art of the Ojhung tradition. So that researchers are interested in conducting research under the title Ojhung Tradition Art as a Sport Tourism Based Development Strategy in Sumenep District.

This research aims to describe the potential of Ojhung traditional arts as sport tourism. This research was expected to be useful in providing a research of cultural-based sport tourism.

\section{METHODS}

This research was descriptive which aimed to obtain a systematic and coherent understanding of the thoughts examined. According to Wardiyanta [10], descriptive research was a research that aimed to make a description of a social or natural phenomenon systematically, factually, and accurately. This research used qualitative methods that could provide a full and comprehensive picture of the potential of Ojhung traditional arts as a sport tourism and development strategy Ojhung tradition tourism based on sport tourism. Data obtained in the form of oral words or language expressions, ways of thinking, views of research subjects through interviews and observations of subject behavior (observation), so that data obtained in the field were able to express the interpretation of the subject of his behavior.

Broadly speaking, data collection in this research was carried out in two ways, they were primary data and secondary data. The primary data collection was carried out in two ways. First, it was through observation. Observation was done by directly observing the art of the Ojhung tradition. During the observation process it would be documented in the form of videos and photos.

Second, it is in-depth interview. Through this technique, the researcher was firstly getting in by interacting with the informant. After getting in successfully, then conducted an indepth interview based on interview guidelines that had been designed beforehand to obtain data about Ojhung tradition arts potential as sport tourism. The type of questions summarized in the interview guidelines are open questions that can provide an opportunity for informants to give answers freely as long as they are in the corridor of the questions asked.

Furthermore, all data obtained in the field, both through the process of observation and in-depth interviews, were recorded in the form of interview transcripts. Records in the form of interview transcripts were then processed in the form of field notes.

Secondary data collection was carried out by searching philosophical books and scientific articles published in national and international scientific journals related to the problems studied. Secondary data were needed to build the initial construction of research which was then needed to assist interpretation in order to obtain a comprehensive and in-depth understanding.

This research used a data analysis model of Miles and Huberman. The steps for data analysis were as follows. First, reducing data by sorting, categorizing, focusing, and compiling data from interviews and observations obtained according to the focus of the research. Before data reduction was done, the interview data were copied in the form of interview transcripts and then processed in the form of field notes. Second, field notes that have been reduced were written in narrative form and compile research results matrices to facilitate theoretical interpretation. Third, doing theoretical interpretations based on data categorization. Fourth, it is making conclusions.

Furthermore, the results of the data analysis were validated using triangulation techniques to check the validity of the data According to Sugiyono [11], triangulation was classified into three, they were time triangulation and data collection, triangulation of data collection techniques, and triangulation of data source. In-depth interviews and observations several times included in the triangulation of data collection time. Triangulation of data collection techniques was done by using several methods in collecting data to obtain data from the same source, including participatory observation, in-depth interviews, and secondary data. Cross-check data obtained from one informant with data obtained from other informants including in the triangulation of data sources.

\section{RESULTS AND DISCUSSION}

\section{A. Potential of Ojhung Tradition Art as Sport Tourism}

Ojhung is a form of tradition that tends to lead to a ritual form, though by means of violence and injury. The Ojhung ritual is held as a traditional ritual of calling for rain carried out by the people of Sumenep District, Madura. The series of activities that exist in the Ojhung ritual aims to gather and communicate with the village community. Ojhung was first performed since the time of the Sumenep Kingdom. The beginning of the emergence of the Ojhung art tradition is that the Madurese had experienced drought. In order for the rain to fall soon, the community held a ritual of salvation at each 
crossing of the road accompanied by Ojhung art. Aside from being a ritual to beg for the fall of rain, Ojhung also aims to keep the community away from distress and disaster.

According to the Chairman of the Ojhung Sapu Angin Association, the Ojhung ritual was vacuumed for seven years. During the vacuum, there was a grandfather who died, at which time he was Chair of the Ojhung Association. In his grave there was always a loud voice, as if someone was crying and someone was fighting. In addition, there are also frequent tornadoes. But after Ojhung was active again, a mysterious voice and a tornado did not appear again in Batuputih.

Ojhung players must be equipped with a rattan instrument called lopalo or kol-pokol; hand protectors made of sarong and tied in the left hand, used to fend off enemy attacks called tangkes; waist protector called amben or kacot; and head protector called pukot. Ojhung is displayed accompanied by okol music. Amazingly the Ojhung player who competed and suffered injuries, their wound can heal in less than 3 hours. Even though previously it was bleeding, but a week later they could play again. Ojhung's players' wound has healed, without using drugs or seeing a doctor. Usually the wound is only given rattan water, then the water is drunk.

Ojhung players are divided into 3 (three) classes, they are heavy class, medium class, and light class. Class classification is based on the number of matches that have been taken by the player. If the player goes through a match less than five times, it is classified as a light class. While the medium class is 5-10 times the match, and the heavy class is more than 10 matches. For selection of opponents, in light classes, it can be done on the day of the match. Whereas the medium class must be chosen first, and for the heavy class is determined one week before the match.

Ojhung Field is made by villagers measuring 2 meters wide and 1 meter length of each plot. Ojhung played one show with 5 (five) matches. One match has 3 (three) rounds, each round played for about 3 minutes. Ojhung can be played by people of various ages, ranging from teenagers to adults. In its history, Ojhung has been played by women, but gradually there are no more enthusiasts. The rules of the Ojhung game, among others, are only allowed from the right or from above; feet must not exceed the center line, if there is a reduction in value; the target of an attack above the waist, such as the abdomen, chest and back; and the rattan must not fall or fall off because it is disqualified. Ojhung's series of activities, starting with greetings, then reading Al-Fatihah for ancestors, then praying, then Ojhung begins. Prior to the Ojhung performance, the brochures were distributed to the Sumenep community as a publication media so that people flocked to see Ojhung. One Ojhung performance was attended by $300-$ 500 spectators.

Ojhung has the potential for attractiveness, including, as a ritual for the fall of rain and as a form of traditional sport that contains the value of sportsmanship. Although Ojhung Sumenep has been staged at the national level at the National Art Festival at TMII in 2013, Ojhung has not yet been included in the Sumenep District Tourism event calendar.

\section{CONCLUSION}

The art of Ojhung tradition has the potential to become a sport tourism in Sumenep District, because it has a tourist attraction, based on its requirements, first, there is a unique ritual for the fall of rain. Second, there will be activities that will be carried out, in the form of participation in Ojhung matches. Third, there are properties that can be purchased, in the form of culinary, Ojhung properties and souvenirs of Sumenep District.

\section{REFERENCES}

[1] Astuti, M.T. dan Noor. A.A., Daya Tarik Morotai Sebagai Destinasi Wisata Sejarah dan Bahari. Jurnal Kepariwisataan Indonesia. 11 (1), pp. 25-46, 2016.

[2] Koran Jakarta. 2018. Pariwisata Potensi Ekonomi Unggulan Sumenep. $<$ http://www.koran-jakarta.com/pariwisata-potensi-ekonomi-unggulansumenep/> diakses tanggal 19 Juni 2019

[3] Samiarta, G., Perkembangan Desa Wisata di Kabupaten Badung (Studi Kasus Desa Wisata Bahari). Jurnal Destinasi Pariwisata. 4 (2), pp.114 $117,2016$.

[4] Hani, T., Persepsi Wisatawan Terhadap Mepantigan Sebagai Pariwisata Alternatif di Pondok Mepantigan di Gianyar Bali. Skripsi Sekolah Tinggi Pariwisata Bali, 2007.

[5] Honari, H., Goudarzi, M., Heidari, A., A Comparison of The Viewpoints of Tourists, Interested Managers and Cultural Heritage Organization Managers Regarding Sport Tourism-Driven Job And Income Creation In Mzandaran-Iran. Procedia Social and Behavioral Scienes. 2, pp.5659 5663, 2010

[6] Palma, D.P., Tafuri, D., Ascione, A., Raiola, G., Social, Tourism and Educational development through Sport. Journal of Physical Education and Sport. 18 (1), pp.473-478, 2018.

[7] Kemenegpora R I., Undang-undang Nomor 3 tahun 2005 tentang Sistem Keolahragaan Nasional. Jakarta:Biro Humas dan Biro Hukum, 2005.

[8] Abbas, A. dan Alrianingrum, S., Kesenian Ojhung Dalam Tradisi Sedekah Bumi di Desa Bunbarat Kecamatan Rubaru Kabupaten Sumenep Tahun 1960-2005. Avatara: Journal Pendidikan Sejarah. 5 (1), pp.81-89, 2017.

[9] Hajar, I., dkk., Aneka Ragam Kesenian Sumenep. Sumenep: Dinas kebudayaan Sumenep, 2004.

[10] Wardiyanta, Metode Penelitian Pariwisata. Yogyakarta: Penerbit Andi, 2010 .

[11] Sugiyono, Metode Penelitian Kuantitatif, Kualitatif, dan R \& D. Bandung: Alfabeta, 2010. 